\title{
Medical Misinformation: Vet the Message!
}

\author{
Joseph A. Hill ${ }^{1}$ Heart Group Signatories
}

Published online: 12 March 2019

(C) The Authors. Published on behalf of the American Heart Association, Inc. 2019

"Mrs. Jones, based on your risk factors for having a heart attack, I recommend that we start you on a statin."

"No, thank you, doctor, I've read too many scary things about those drugs on the internet. Plus, I worry that some in your profession make these recommendations for reasons of personal financial gain. I also found that online."

Undoubtedly, the majority of cardiologists have had conversations just like this, urging a patient to take a statin, a powerful cholesterol-lowering drug with robust mortality benefit. Part of the reason these oftentimes no brainer recommendations are rejected derives from widely disseminated incorrect information that vastly over-states the risks of these drugs. (Of course, like anything in life, the use of statins is not entirely risk-free; their application should always entail a thoughtful analysis of risks versus benefits.) Most patients do not recognize that the benefits of statin use are invisible ("I didn't have a heart attack or stroke this past year."), whereas the small and typically reversible risks (e.g., muscle pain) are readily apparent. Many patients who would benefit from statin use do not take them.

Cardiovascular disease is the No. 1 killer of both men and women around the world. Robust scientific advances, published in the pages of our journals, have fostered significant improvements that benefit individuals and society. Yet, cardiovascular disease continues to transform itself, emerging in new forms, such as heart failure. The struggle has shifted to new battlefields.

These successes derive from an armamentarium of powerful tools, medicines, devices, and awareness of lifestylerelated hazards, such as high blood pressure, high cholesterol,

Joseph A. Hill

joseph.hill@utsouthwestern.edu

1 Medical Center Internal Medicine, University of Texas

Southwestern, NB11.200, UT Southwestern 6000 Harry Hines Blvd, Dallas, TX 75390-8573, USA and smoking. Sadly, however, we do not take full advantage of the tools at our disposal.

One significant cause of suboptimal utilization of our prodigious tool chest is medical misinformation hyped through the Internet, television, chat rooms, and social media. In many instances, celebrities, activists, and politicians convey false information; not uncommonly, authors with purely venal motives participate.

We can point to numerous other examples, including the entirely unfounded concerns regarding vaccinations. The notion that MMR (measles, mumps, rubella) vaccination causes autism was based on a single, flawed study, long since refuted, with its publication retracted. Seventeen much larger and properly controlled studies have proven otherwise. Nevertheless, the Internet shouts unfounded warnings. Once again, celebrities, actors, activists, and politicians with no specific knowledge or training use their fame to promote a message that causes serious harm. Individuals who are neither physicians nor scientists, but often with a specific agenda, have outsized influence over our lives. They dispute scientific evidence without ever having studied it [1].

Recognizing that it is impossible to prove "never," scientists appropriately couch their statements in statistical terms, which may come across to the public as equivocation. The nuanced voices of scientists often do not resonate with the public as much as the strident alarms sounded by people of fame, speaking in absolute terms.

Furthermore, scientists are appropriately skeptical, as any individual scientist or study can be wrong. Yet, science ultimately self-corrects. When a scientist gets it wrong, as happens, people sometimes vilify the entire self-correcting scientific enterprise. We trust aeronautical science when we board an airplane; we trust the science buried within our cell phones; we trust mechanical engineering science when we cross a bridge; yet, many are uniquely skeptical of biological science.

Sadly, we cannot exclude that some in the professions of science and medicine act based on motives driven by financial 
considerations; incomplete declarations of potential conflict of interest persist [2]. Recent examples of dramatic price hikes for important medications have reinforced this notion. Indeed, many physicians have had conversations with patients who believe that our recommendations stem, at least in part, from the prospect of personal financial gain.

We, the editors-in-chief of the major cardiovascular scientific journals around the globe, sound the alarm that human lives are at stake. Pointing to the 2 examples elaborated above, people who decline to use a statin when recommended by their doctor, or parents who withhold vaccines from their children, put lives in harm's way.

The media must do a better job. It is unacceptable to posit false equivalents in these discussions, often done to foster debate and controversy. It is easy to find a rogue voice but inappropriate to suggest that voice carries the same weight as that emerging from mainstream science. (We can easily point to examples outside the medical domain, as well, such as climate change, evolution, nutraceuticals, and genetically modified foods, where false equivalents are frequently posited.) Furthermore, recent evidence suggests that misinformation travels faster through social networks than truth [3]. We must work to enhance science literacy in our world; one place to start is by doing a better job of teaching the scientific method in our schools so that the lay public is aware that science is accomplished in fits and starts, but, in the end, gets it right.

Purveyors of social media must be responsible for the content they disseminate. It is no longer acceptable to hide behind the cloak of platform. We, as editors, are charged with evaluating the validity of the science presented to us for possible publication, and we work hard to fulfill this heady responsibility. Recognizing that lives are at stake, we reach out to thought-leading experts to evaluate the veracity of each report we receive. Here, we challenge social media to do the same, to leverage the ready availability of science-conversant expertise before disseminating content that may not be reliable.

Without exaggeration, significant harm, to society and individuals, derives from the wanton spread of medical misinformation. It is high time that this stop, and we lay at the feet of the purveyors of internet and social media content the responsibility to fix this.

Acknowledgments Heart Group Signatories:

Joseph A. Hill, MD, PhD, Editor-in-Chief, Circulation; Stefan Agewall, MD, PhD, Editor-in-Chief, European Heart Journal Cardiovascular Pharmacotherapy; Adrian Baranchuk, MD, Editor-inChief, Journal of Electrocardiology; George W. Booz, PhD, Editor-inChief, Journal of Cardiovascular Pharmacology; Jeffrey S. Borer, MD, Editor-in-Chief, Cardiology; Paolo G. Camici, MD, Editor-in-Chief, International Journal of Cardiology; Peng-Sheng Chen, MD, Editor-inChief, HeartRhythm; Anna F. Dominiczak, DBE, MD, Editor-in-Chief, Hypertension; Çetin Erol, MD, PhD, Editor-in-Chief, Anatolian Journal of Cardiology; Cindy L. Grines, MD, Editor-in-Chief, Journal of Interventional Cardiology; Robert Gropler, MD, Editor-in-Chief, Circulation: Cardiovascular Imaging; Tomasz J. Guzik, MD, PhD, Editor-in-Chief, Cardiovascular Research; Markus K. Heinemann, MD, $\mathrm{PhD}$, Editor-in-Chief, The Thoracic and Cardiovascular Surgeon; Ami E. Iskandrian, MD, Editor-in-Chief, Journal Nuclear Cardiology; Bradley P. Knight, MD, Editor-in-Chief, PACE and EPLab Digest; Barry London, MD, PhD, Editor-in-Chief, Journal of the American Heart Association; Thomas F. Lüscher, MD, Editor-in-Chief, European Heart Journal; Marco Metra, MD, Editor-in-Chief, European Journal of Heart Failure; Kiran Musunuru, MD, PhD, MPH, Editor-in-Chief, Circulation: Genomic and Precision Medicine; Brahmajee K. Nallamothu, MD, MPH Editor-in-Chief, Circulation: Cardiovascular Quality and Outcomes; Andrea Natale, MD, and Sanjeev Saksena, MD, Editors-in-Chief, Journal of Interventional Cardiac Electrophysiology; Michael H. Picard, MD, Editor-in-Chief, Journal of the American Society of Echocardiography; Sunil V. Rao, MD, Editor-in-Chief, Circulation: Cardiovascular Interventions; Willem J. Remme, MD, $\mathrm{PhD}$, and Robert S. Rosenson, MD, Editors-in-Chief, Cardiovascular Drugs and Therapy; Nancy K. Sweitzer, MD, PhD, Editor-in-Chief, Circulation: Heart Failure; Adam Timmis, MD, Editor-in-Chief, European Heart Journal: Quality of Care and Clinical Outcomes; Christiaan Vrints, MD, PhD, Editor-in-Chief, European Heart Journal: Acute Cardiovascular Care.

Circulation, 2019; 139:571-572, American Heart Association. DOI: https://doi.org/10.1161/CIRCULATIONAHA.118.039193. Simultaneously published in multiple journals. A complete list of all journals co-publishing this article, along with links to the individual articles, can be found online at https://www.ahajournals.org/circ/medical-misinformation

\section{Compliance with Ethical Standards}

Disclosures P.G. Camici is consultant for Servier. R.S. Rosenson reports research grants to his institutions from Akcea, Amgen, Astra Zeneca, Medicines Company and Regeneron. R.S. Rosenson reports speaking engagements at Amgen and Kowa, research consulting for Akcea and Regeneron, royalties from UpToDate, Inc. and stock holdings in MediMergent. All other authors have nothing to disclose.

The opinions expressed in this article are not necessarily those of the editors or of the American Heart Association.

\section{References}

1. Offit PA. Bad advice: or why celebrities, politicians, and activists Aren't your best source of health information. New York: Columbia University Press; 2018.

2. Orenstein $\mathrm{C}$, Thomas $\mathrm{K}$. Top cancer researcher fails to disclose corporate financial ties in major research journals. New York Times. https:// www.nytimes.com/2018/09/08/health/jose-baselga-cancer-memorialsloankettering.html. September 8, 2018. Accessed 11 Dec 2018.

3. Vosoughi S, Roy D, Aral S. The spread of true and false news online. Science. 2018;359:1146-51.

Publisher's Note Springer Nature remains neutral with regard to jurisdictional claims in published maps and institutional affiliations. 